Doi: HTTPS://DOI.ORG/10.23910/IJBSM/2017.8.2.1777a

\title{
Appropriate Nitrogen Schedules in Direct Seeded Rice (Oryza sativa L.)
}

\author{
Jagmohan Kaur* and Jagroop Kaur
}

Dept. of Agronomy, Punjab Agricultural University, Ludhiana, Punjab (141 004), India

\section{Corresponding Author}

Jagmohan Kaur

e-mail: jagmohanpau3@gmail.com

\author{
Article History \\ Manuscript No. AR1777a \\ Received in $11^{\text {th }}$ January, 2017 \\ Received in revised form 21 ${ }^{\text {st }}$ March, 2017 \\ Accepted in final form $7^{\text {th }}$ April, 2017
}

\begin{abstract}
Nitrogen being a key nutrient in promoting the plant growth, plays an important role in determining the yield potential of rice. But in case of rice, recovery of applied nitrogen is very low on account of various losses viz., ammonia volatilization, denitrification, run off and leaching. Moreover, transplanted rice is being replaced by aerobic rice culture for saving water, labour as well as energy. In contrary to flooded conditions, the dominant form of nitrogen is nitrate under aerobic conditions and further alternate wet and dry conditions stimulate nitrification and denitrification processes which increase $\mathrm{N}$ losses and relatively low $\mathrm{N}$ uptake by DSR makes nitrogen management even more dynamic. Application of nitrogen at the stages which coincide with the period of efficient utilization, is of immense importance to meet the nitrogen requirement of direct seeded rice (DSR) throughout the growing season. Thus, improvement in $\mathrm{N}$ management can be done by adopting those strategies which are based on the requirement as well as temporal variation in crop $\mathrm{N}$ demand. This paper reviews the information regarding influence of various nitrogen application schedules on various aspects like yield and quality of DSR. In DSR, those $\mathrm{N}$ schedules should be prefered which avoid basal $\mathrm{N}$ application to the crop as it remain unutilized by the crop and is lost and also encourages weed growth.
\end{abstract}

Keywords: Aerobic rice, nitrogen, nutrient uptake, quality, splits

\section{Introduction}

Fertilizer is an expensive input in agriculture, thus making the determination of its appropriate method of application immense important for enhancing productivity as well as profitability. Moreover, the shortage of major fertilizer nutrients especially nitrogen is being faced by the world. Nitrogen is a key nutrient in promoting the plant growth and determining the yield potential of rice. Synchronization of nitrogen demand and supply is very important to meet the nitrogen requirement of crop throughout the growing season.

Split application of nitrogen is a well accepted method of increasing nitrogen use efficiency especially under irrigated conditions. This is also highly desirable in rice since this crop takes up very small amounts of $\mathrm{N}$ which varies to the tune of 1-1.2 $\mathrm{kg} \mathrm{ha}^{-1} \mathrm{day}^{-1}$ (Prasad, 2006). Excess nitrogen which is not used by the crop is subjected to various mechanisms of losses (Prasad et al., 1999; Adhya et al., 2007; Pathak et al., 2008). The potential loss mechanisms are ammonia volatilization, denitrification, run off and leaching (Crasswell and Vlek, 1982).

The scenario under aerobic rice is entirely different from puddled transplanted rice. In aerobic rice, the dominant form of $\mathrm{N}$ is nitrate and the alternate wetting and drying leads to high nitrogen losses due to nitrification under dry conditions and denitrification under submerged conditions. Applied $\mathrm{N}$ is lost to the extent of $22-33 \%$ due to denitrification only (Aulakh et al., 2001). Correct timing of $\mathrm{N}$ application in rice is most crucial for its overall management. Thus, exploring the most appropriate $\mathrm{N}$ application strategy is very important to enhance the yield as well as quality of direct seeded rice (DSR).

\section{Nitrogen Schedules and DSR}

\subsection{Effect of nitrogen schedules on crop productivity}

Several workers (Patel and Thakur, 1997; Ehsanullah et al., 2001; Manzoor et al., 2005) reported that the levels and time of nitrogen application play an important role in increasing rice production. They reported higher paddy yield (4-5 $\left.\mathrm{t} \mathrm{ha}^{-1}\right)$, where nitrogen fertilizer was applied in two or three splits as compared to full nitrogen application at the time of transplanting.

In direct-seeded upland rice at Sabour, a field investigation was performed to study the effect of nitrogen management by Sharma et al. (2007). They obtained significantly higher grain and straw yields where nitrogen was applied in 3 splits $\left(1 / 2\right.$ at $20 \mathrm{DAS}+1 / 4^{\text {th }}$ at tillering $+1 / 4^{\text {th }}$ at panicle initiation) where basal was omitted in comparison with the 
splits where a part of nitrogen was applied at sowing. Field experiments were conducted in Tamil Nadu by Thilagavathi and Ramanathan (2005) to study the effect of timing and rate of $\mathrm{N}$ application on the yield of direct-sown rice under lowland conditions. $\mathrm{N}$ application in 4 splits (17\% at 21 days after sowing (DAS), 33\% at 35 DAS, 33\% at panicle initiation and $17 \%$ at first flowering gave significantly higher grain yield (4.18 $\mathrm{t} \mathrm{ha}^{-1}$ ) and nitrogen use efficiency (NUE) (14.0) than $\mathrm{N}$ in 4 equal splits ( $25 \%$ basal, $25 \%$ at 35 DAS, $25 \%$ at panicle initiation and $25 \%$ at first flowering which had lower grain yield (3.44 t ha-1) and NUE (8.1). In similar studies, Sathiya and Ramesh (2009) found that $N$ application in 4 splits viz., $1 / 6^{\text {th }}$ at $15 \mathrm{DAS}, 1 / 3^{\text {rd }}$ at tillering, $1 / 3^{\text {rd }}$ at panicle initiation, $1 / 6^{\text {th }}$ at flowering produced higher grain and straw yields ( 2.83 and $4.92 \mathrm{t} \mathrm{ha}^{-1}$ respectively) as compared to 4 equal splits $\left(1 / 4^{\text {th }}\right.$ at each stage $)$ and 4 unequal splits $\left(1 / 5^{\text {th }}\right.$ at 15 DAS, $1 / 5^{\text {th }}$ at tillering, $2 / 5^{\text {th }}$ at panicle initiation, $1 / 5^{\text {th }}$ at flowering).

The rice yield was significantly affected by nitrogen application schedules involving different growth stages (Kenzo, 2004). Nitrogen application in three equal splits i.e. at sowing, tillering and panicle emergence stage gave the highest grain yield of $4.92 \mathrm{t} \mathrm{ha}^{-1}$ which was statistically at par with that obtained from application of $\mathrm{N}$ in 2 splits i.e. $1 / 2$ at tillering $+1 / 2$ at panicle emergence stage $(4.90 \mathrm{t}$ ha $^{-1}$ ) (Ehsanullah et al., 2001). In Bengaluru, Narayan et al. (2017) found that 4 split $N$ application to aerobic rice $(25 \%$ basal $+25 \%$ at tillering $+25 \%$ at panicle initiation $+25 \%$ at panicle emergence) produced significantly higher grain yield (6.69 $\left.\mathrm{t} \mathrm{ha}^{-1}\right)$, which was satistically at par with the application of nitrogen in 3 splits ( $33 \%$ basal $+33 \%$ at tillering $+33 \%$ at panicle initiation) (6.29 $\mathrm{t} \mathrm{ha}^{-1}$ ) followed by application of nitrogen in 3 splits ( $50 \%$ basal $+25 \%$ at tillering $+25 \%$ at panicle initiation) (6.20 $\mathrm{t} \mathrm{ha}^{-1}$ ) compared to application of nitrogen in 2 splits (50\% at 15 days after emergence $+50 \%$ at panicle initiation) (5.33 $\left.\mathrm{t} \mathrm{ha}^{-1}\right)$.

In three and four $\mathrm{N}$ split application studies in DSR, Mahajan et al. (2011a) found that the application of $3 \mathrm{~N}$ splits viz., basal, 21 and 42 DAS, did not increase the yield with increasing $\mathrm{N}$ levels from 120 to $180 \mathrm{~kg} \mathrm{ha}^{-1}$ in contrary to four split modules viz., basal, 21, 42 and 63 DAS and four equal splits at 15, 30, 40 , and 60 DAS. In case of 4 split application of $N$, where no nitrogen was applied at sowing, increasing $\mathrm{N}$ application from 120 to $150 \mathrm{~kg} \mathrm{ha}^{-1}$ resulted in highest yield to the tune of 7.55 and $7.76 \mathrm{t} \mathrm{ha}^{-1}$ yields in first and second year, respectively; which was highest among all the treatments. Based on the study conducted at Ludhiana, Ali et al. (2015) found that the best $N$ schedules for DSR are viz., 14,28,49 and 70 DAS in case of 4 split doses and 14, 42 and 70 DAS in case for 3 split doses.

In semi-dry rice, Jhansi et al. (2013) studied the levels (60, 80,100 and $120 \mathrm{~kg} \mathrm{ha}^{-1}$ ) as well as time of $\mathrm{N}$ application and found that application of $120 \mathrm{~kg} \mathrm{ha}^{-1}$ produced highest grain yield and among the different $\mathrm{N}$ schedules, $\mathrm{N}$ application in 4 splits i.e. $1 / 4^{\text {th }}$ each at basal, conversion to wet, panicle initiation and flowering lead to higher productivity. Singh et al. (2015) at Pantnagar under Tarai conditions studied three $\mathrm{N}$ levels $\left(90,120\right.$ and $\left.150 \mathrm{~kg} \mathrm{ha}^{-1}\right)$ and seven $\mathrm{N}$ schedules viz., 2 equal splits (basal+at panicle initiation), 2 equal splits (10-12 days after emergence+at panicle initiation), 3 equal splits (basal+at active tillering+at panicle initiation), 3 equal splits (10-12 days after emergence+at active tillering+at panicle initiation), 4 equal splits (basal+at active tillering+at panicle initiation+at flowering), 4 equal splits (10-12 days after emergence+at active tillering+at panicle initiation+at flowering) and 3 splits ( $1 / 4^{\text {th }}$ basal $+1 / 2$ at active tillering $+1 / 4^{\text {th }}$ at panicle initiation) in DSR. They found that $150 \mathrm{~kg} \mathrm{~N} \mathrm{ha}^{-1}$ produced significantly higher yield as compared to 90 and $120 \mathrm{~kg} \mathrm{~N} \mathrm{ha}^{-1}$. Among the nitrogen schedules, the grain yield (4.78 $\mathrm{t} \mathrm{ha}^{-1}$ ) was maximum when $\mathrm{N}$ was applied in 4 equal splits (basal+at active tillering+panicle initiation+at flowering), and statistically at par with 4 equal splits (10-12 days after emergence+at active tillering+at panicle initiation+at flowering) (4.56 t ha- $\left.{ }^{-1}\right)$ and 3 splits $\left(1 / 4^{\text {th }}\right.$ basal $+1 / 2$ at active tillering $+1 / 4^{\text {th }}$ at panicle initiation) $\left(4.60 \mathrm{t} \mathrm{ha}^{-1}\right)$ and was significantly higher than rest of the schedules. Among different $\mathrm{N}$ schedules involving a part of $\mathrm{N}$ application at sowing, Yoseftabar (2013) also reported maximum grain yield (7.82 $\mathrm{t} \mathrm{ha}^{-1}$ ) when $\mathrm{N}$ was applied in 4 equal splits (basal+at mid tillering+panicle initiation+at flowering). Similar results were also reported by Devi et al. (2012) in scented rice.

In a study on direct seeded basmati rice (DSBR), Mahajan et al. (2011b) found that increasing splits (2 splits i.e. 21 and 42 DAS to 3splits i.e., 21, 42 and 63 DAS) with $40 \mathrm{~kg} \mathrm{~N}^{-1}$ had no influence on grain yield in contrast to increasing splits ( 2 to 3 splits) with $60 \mathrm{~kg} \mathrm{~N} \mathrm{ha}^{-1}$ which resulted in significantly higher grain yield than 2 splits. In another study conducted at Ludhiana, Kaur et al. (2016) found that two modules of N splits [3 splits, i.e. application at 3, 6 and 9 weeks after sowing (WAS) and 4 splits, i.e. application at 0, 3, 6 and 9 WAS] produced statistically similar yields in DSBR.

Thus, N splits more closely match uptake patterns than single large dose by reducing the losses and enhancing of nitrogen use efficiency. The splits where basal $\mathrm{N}$ application are avoided, help to increase the $\mathrm{N}$ use efficiency (Ali et al., 2015). The application of $\mathrm{N}$ at the growth stages like active tillering, panicle initiation and panicle emergence is beneficial to rice crop which might be due to the fact that $\mathrm{N}$ application at or after anthesis increases post anthesis dry matter accumulation and thus causes more grain filling (Zhang et al., 2009).

\subsection{Effect of nitrogen schedules on growth and yield attributes}

In a field investigation at Sabour, Sharma et al. (2007) studied the effect of nitrogen management in direct-seeded upland rice. The $\mathrm{N}$ modules in which basal application of nitrogen was skipped off had resulted in significantly higher yield attributes in comparison with those wherein part of nitrogen was applied at sowing. Similarly, Kumar et al. (2015) also reported that the yield attributes viz., effective tillers $\mathrm{m}^{-2}$, number of grains panicle $^{-1}$, panicle length, weight of panicle and test weight of 
DSR were maximum under $\mathrm{N}$ schedule of $1 / 4^{\text {th }}$ each at 2,4 , 6 and 8 WAS, statistically at par with other $N$ schedules viz., $1 / 3^{\text {rd }}$ each at 2, 4 and 6 WAS and significantly higher than $1 / 2$ basal $+3 / 4^{\text {th }} 4$ WAS and $1 / 4^{\text {th }}$ basal $+1 / 2^{\text {th }} 4$ WAS $+1 / 4^{\text {th }} 6$ WAS.

In a field experiment on dry seeded aerobic rice, Mahajan et al. (2011a) studied $\mathrm{N}$ rates as well as $3 \mathrm{~N}$ modules viz., 3 N splits: basal, 21 and 42 DAS; $4 \mathrm{~N}$ splits (with basal):basal, 21, 42 and 63 DAS and $4 \mathrm{~N}$ splits (without basal):15, 30, 40, and 60 DAS. Four $\mathrm{N}$ splits increased the yield with increasing $\mathrm{N}$ levels from 120 to $180 \mathrm{~kg} \mathrm{ha}^{-1}$ as compared to 3 splits. Application of $150 \mathrm{~kg} \mathrm{~N} \mathrm{ha}^{-1}$ in 4 splits viz., 15, 30, 40, and 60 DAS (No basal dose) produced significantly higher panicles $\mathrm{m}^{-2}$, filled grains panicle $\mathrm{e}^{-1}$ and 1000 grain weight as compared to application of $120 \mathrm{~kg} \mathrm{~N} \mathrm{ha}^{-1}$ in three split doses. In contrary to this, Singh et al. (2015) in tarai region of Pantnagar found significantly higher yield attributing characters of DSR viz., 1000 grain weight and panicle weight, when $\mathrm{N}$ was applied in 4 equal splits (basal+at active tillering+panicle initiation+at flowering) as compared to rest of the treatments except in panicle weight in which this $\mathrm{N}$ schedule was statistically similar with $3 \mathrm{~N}$ splits $\left(1 / 4^{\text {th }}\right.$ basal $+1 / 2$ at active tillering $+1 / 4^{\text {th }}$ at panicle initiation). In DSBR, Mahajan et al. (2011b) found that the increase in grain yield in response to $60 \mathrm{~kg} \mathrm{ha}^{-1}$ of $\mathrm{N}$ in 3 splits (21, 42 and 63 DAS) was attributed to higher panicle $\mathrm{m}^{-2}$ and grain panicle ${ }^{-1}$ as compared to $40 \mathrm{~kg} \mathrm{ha}^{-1}$ of $\mathrm{N}$ applied in either 2 (i.e., 21 and 42 DAS) or 3 splits.

Application of nitrogen at later stages as compared to that at sowing delays abscisic acid synthesis, promotes cytokinin activity and more chlorophyll retention; thus resulting in more translocation of photosynthates to grains (Sarkar et al., 2007).

\subsection{Effect of nitrogen schedules on nutrient uptake}

Nitrogen management practices significantly increased the uptake of NPK in direct seeding. Application of $\mathrm{N}$ at four splits viz., $1 / 4^{\text {th }} \mathrm{N}$ each at early tillering, active tillering, panicle initiation and panicle emergence recorded maximum nutrient (N, P and K) uptake which was significantly superior over other practices (control, 3 splits and 5 splits) (Chaudhary et al., 2011). Sharma et al. (2007) at Sabour found that the splits where no basal application of nitrogen was applied resulted in significantly higher nutrient uptake by direct-seeded upland rice crop in comparison with splits where $\mathrm{N}$ was applied at sowing, thus resulting in higher $\mathrm{N}$-use efficiency.

Under tarai conditions of Pantnagar, Singh et al. (2015) found that variable nitrogen schedules had significant effect on total $\mathrm{N}$ uptake by DSR and $\mathrm{N}$ schedule of 3 splits i.e., $1 / 4^{\text {th }}$ as basal, $1 / 2$ at active tillering and remaining $1 / 4^{\text {th }}$ at panicle initiation showed significantly higher $\mathrm{N}$ uptake by rice (183 kg ha-1) which was statistically at par with $\mathrm{N}$ schedule of 4 equal splits ( basal, at active tillering, at panicle initiation and at flowering (182 $\mathrm{kg} \mathrm{ha}^{-1}$ ). Ali et al. (2015) reported that $\mathrm{N}$ uptake rate was very slow during the initial stages whereas the highest values were obtained during the two critical stages i.e., 42-56 DAS (active tillering stage) and 70-84 DAS (panicle initiation to booting growth stage); thus, application of $\mathrm{N}$ should be ensured at these two critical stages.

In DSBR, Kaur and Mahal (2014) found that the nitrogen application modules viz., 3 equal splits, i.e. 3, 6 and 9 WAS and 4 equal splits, i.e. basal, 3, 6 and 9 WAS, failed to exhibit any significant effect on $\mathrm{N}, \mathrm{P}$ or $\mathrm{K}$ uptake by paddy grains as well as straw.

\subsection{Effect of nitrogen schedules on weeds}

One of the major disadvantages of applying all the nitrogen at planting is that it induces excessive foliage and encourages weed growth. In a study conducted at Pusa (Bihar), Chaudhary et al. (2011) found that N splits resulted in significant variation on weed density and dry weight of weeds. Application of $\mathrm{N}$ in three splits viz., $1 / 2 \mathrm{~N}$ at sowing, $1 / 4^{\text {th }}$ each at tillering and panicle initiation recorded significantly higher values of weed density and dry weight of weed. The least values of weed density and dry weight of weeds were obtained in $4 \mathrm{~N}$ splits viz., $1 / 4^{\text {th }} \mathrm{N}$ each at early tillering, active tillering, panicle initiation and panicle emergence which might be because of least $N, P$ and $K$ uptake by the weeds which was significantly lower than the uptake in $3 \mathrm{~N}$ splits. Kumar et al. (2015) also found that $\mathrm{N}$ schedule viz., $1 / 4^{\text {th }}$ basal $+3 / 4^{\text {th }} 4$ WAS and $1 / 4^{\text {th }}$ basal $+1 / 2$ at 4 WAS $+1 / 4^{\text {th }} 6$ WAS recorded higher weed density and dry weight whereas minimum was recorded in $\mathrm{N}$ schedule of four nitrogen splits i.e. 1/4 $4^{\text {th }}$ each at 2, 4, 6 and 8 WAS followed by 3 splits i.e. $1 / 3^{\text {rd }}$ each at 2,4 and 6 WAS. Thus, application of $\mathrm{N}$ in early stages of crop establishment encourage weed growth because of less competition offered by slow growing crop.

\subsection{Effect of nitrogen schedules on quality of rice}

The judicious use of nitrogen fertilizer contributes a lot towards improving the yield and quality of grain. Various workers reported that nitrogen application during the postanthesis phase increases the protein content of rice grains and improves their nutritive quality (Souza et al., 1993).

The grain quality parameters like hulling $\%$, milling $\%$, head rice recovery, L/B ratio and amylose content were analysed and most of the characters were found to be remained unaffected due to nitrogen management practices, except milling percentage and head rice recovery which were found to be statistically superior when $\mathrm{N}$ was applied in four equal amounts at early tillering, active tillering, panicle initiation and panicle emergence (Chaudhary et al., 2011). In a study conducted on DSBR cultivar "Pusa Basmati 1121" at Ludhiana, Kaur et al. (2016) found that various parameters viz., hulled (brown), milled and head rice recovery, $\mathrm{hl}$ weight, L/B ratio, protein, amylose and amylopectin content as well as the cooking quality were not affected by two modules of $\mathrm{N}$ splits (3 splits, i.e. application at 3, 6 and 9 WAS and 4 splits, i.e. application at 0, 3, 6 and 9 WAS).

\section{Conclusion}

Keeping in view, the low nitrogen use efficiency, best time of 
nitrogen application for getting maximum yield and quality of direct seeded rice is imperative for judicious and economical use of nitrogen fertilizer. From the above review, it can be concluded that in DSR, nitrogen application at tillering, panicle initiation and panicle emergence resulted in higher yields, nutrient uptake and grain quality. Avoid basal $\mathrm{N}$ dose to DSR as it remains unutilized by the crop due to insufficient root development.

\section{References}

Adhya, T.K., Pathak, H., Chhabra, A., 2007. N-fertilizers and gaseous- $\mathrm{N}$ emission from rice-based cropping systems. In: Abrol, Y.P., Raghuram, N., Sachdev, M.S., (eds) Agricultural Nitrogen Use and its Environmental Implications. I.K. Pub. House Pvt. Ltd., New Delhi, 459-476.

Ali, A.M., Thind, H.S., Sharma, S., Singh, Y., 2015. Site-specific nitrogen management in dry direct-seeded rice using chlorophyll meter and leaf colour chart. Pedosphere 25, 72-81.

Aulakh, M.S., Khera, M.S., Doran, J.W., Bronson, K.F., 2001. Denitrification, nitrous oxide and carbon dioxide fluxes in rice-wheat cropping systems as affected by crop residues, fertilizer nitrogen and green manure. Biology and Fertility of Soils, 34, 375-389.

Chaudhary, S.K., Jha, S., Sinha, N.K., 2011. Influence of nitrogen and weed management practices on productivity and nutrient uptake of wet direct seeded rice. Oryza 48, 222-225.

Crasswell, E.T., Vlek, P.L.G., 1982. Yield and harvest index responses to pre-flood nitrogenfertilization at low rice plant populations. Journal of Production Agriculture 5, 492-497.

Devi, M.G., Reddy, S.T., Sumati, V., Pratima, T., John, K., 2012. Nitrogen management to improve the nutrient uptake, yield and quality parameters of scented rice under aerobic culture. International Journal of Applied Biology and Pharmaceutical Technology 3, 340-344.

Attaullah, E., Cheema, M.S., Usman, M., 2001. Rice Basmati-385 response to single and split application of nitrogen at different growth stages. Pakistan Journal of Agricultural Sciences 38, 84-86.

Jhansi Lakshmi Bai, K., Murthy, K.V.R., Naidu, M.V., 2013. Effect of graded levels and time of nitrogen application on nutrient uptake, yield and economics of semi-dry rice Oryza sativa L. Journal of Research ANGRAU 41, 21-25.

Kaur, J., Mahal, S.S., 2014. Effect of irrigation schedules and nitrogen levels on direct seeded scented basmati rice (Oryza sativa L.). Journal of Research, PAU 51 (2), 119-123.

Kaur, J., Mahal, S.S., Kaur, A., 2016. Yield and quality evaluation of direct seeded basmati rice (Oryza sativa L.) under different irrigation and nitrogen regimes. Cereal Research Communications 44(2), 330-340.
Kenzo, W., 2004. Utilization advantages of controlled release nitrogen fertilizer on paddy rice cultivation. Japan Agricultural Research Quarterly 38, 15-20.

Krishnan, P., Nayak, S.K., 2000. Biomass partitioning and yield components of individual tillers of rice (Oryza sativa) at different nitrogen levels. Indian Journal of Agricultural Sciences 70, 143-145.

Kumar, S., Singh, R.K., Meena, R.N., Singh, S.P., 2015. Effect of nitrogen scheduling and weed management on weed density, growth and yield of direct-seeded rice (Oryza sativa L.). Research on crops 16, 643-652.

Mahajan, G., Chauhan, B.S., Gill, M.S., 2011a. Optimal nitrogen fertilization timing and rate in dry-seeded rice in northwest India. Agronomy Journal 103, 1676-1682.

Mahajan, G., Singh, J., Sharma, N., 2011b. Enhancing the performance of direct seeded basmati rice through seed priming and nitrogen management. Oryza 48(4), 380-382.

Manzoor, Z., Awan, T.H., Safdar, M.E., Akhtar, M., Hussain, S., Ashraf, M.M., 2005. Effect of different nitrogen levels on yield and yield components of Basmati-2000. Proceedings International Seminar on Rice Crop, Oct. 2-3, 2005. Rice Research Institute Kala Shah Kaku, Pakistan 130-134.

Narayan, H., Ramachandra, C., Kalyanmurthy, K.N., Mallareddy., Prabhudev, D.S., 2017. Effect of nitrogen level and time of application on yield and water use efficiency of aerobic rice. International Journal of Agriculture Sciences 9, 3690-3693.

Patel, S.R., Thakur, D.S., 1997. Yield of rice as influenced by split application of nitrogen. Journal of Maharashtra Agricultural Universities 22, 215-216.

Pathak, H., Bhatia, A., Jain, N., Mohanty, S., Chandrasekharan, S., 2008. Nitrogen, phosphorus and potassium budgets in Indian Agriculture. Proceedings Indian Science Congress, Andhra University, Visakhapatnam, 3-7 January, 2008, 45.

Prasad, R., 2006. Nitrogen uptake pattern as a guide for nitrogen application practices in rice. Indian Journal of Fertilizers 2, 39-44.

Prasad, R., Singh, D.K., Singh, R.K., Archna, Ranni., 1999. Ammonia volatilization in rice-wheat cropping system and ways to minimize it. Fertiliser News 44, 53-56.

Sarkar, R.K., Deb, N., Parya, M.K., 2007. Effect of seed treatment and foliar nutrition on growth and productivity of spring sunflower (Helianthus annuus). Indian Journal of Agricultural Sciences 77, 191-194.

Sathiya, K., Ramesh, T., 2009. Effect of split application of nitrogen on growth and yield of aerobic rice. Asian Journal Experimental Science 23, 303-306.

Sharma, R.P., Pathak, S.K., Singh, R.C., 2007. Effect of nitrogen and weed management in direct seeded rice (Oryza sativa) under upland conditions. Indian Journal of Agronomy 52, 114-119. 
Singh, D.K., Pandey, P.C., Priyanker, Qureshi, A., Gupta, S., 2015. Nitrogen management strategies for direct seeded aerobic rice (Oryza sativa L.) grown in mollisols of Uttarakhand (India). International Journal of Applied and Pure Science and Agriculture 1(7), 130-138.

Souza, S.R., Stark, E.M.L.M., Fernandes, M.S., 1993. Effects of supplemental- $\mathrm{N}$ on the quality of rice proteins. Journal of Plant Nutrition 16, 1739-1751.

Thilagavathi, T., Ramanathan, S., 2005. Nitrogen management for direct wet-seeded rice. International Rice Research Notes 30, 44-45.

Yoseftabar, S., 2013. Effect nitrogen management on panicle structure and yield in rice (Oryza sativa L.). International Journal of Agriculture and Crop Sciences 5, 1224-1227.

Zhang, L., Shah, L., Bouman, B.A.M., Xue, C., Wei, F., Tao, H., 2009. Response of aerobic rice growth and grain yield to $\mathrm{N}$ fertilizer at two contrasting sites near Beijing, China. Field Crops Research 114, 45-53. 